Pembelajarannya

ISSN:2654-2587 (Print); ISSN:2654-735X (Online)

Volume IV, Nomor 1, Tahun 2021, Hal. 56 - 64

Available online at:

http://ejurnal.budiutomomalang.ac.id/index.php/alfabeta

Research Article

\title{
Terapi Menulis untuk Meningkatkan Kemampuan Kognitif Pecandu Narkoba di Lapas Dewasa Kota Blitar
}

\author{
Miza Rahmatika Aini ${ }^{1}$, Hesty Puspitasari ${ }^{2}$ \\ Program Studi Pendidikan Bahasa Inggris Universitas Islam Balitar \\ jumintenlarasati@gmail.com, hestypuspita1403@gmail.com
}

\begin{tabular}{ll}
\hline Informasi Artikel & \multicolumn{1}{c}{ ABSTRACT } \\
\hline Submit: $05-01-2021$ & ABSTRACT \\
Diterima: $21-04-2021$ & In this sophisticated modern era, drugs have become a problem \\
Dipublikasikan: $26-04-2021$ & for mankind in various parts of the world. Drugs that can \\
destroy common sense destroy body and soul, inevitably can \\
threaten the future of mankind. In life, a critical step of the \\
neurodevelopmental process, drug abuse can be caused by the \\
plasticity mechanism of the brain which can lead to long-term \\
improvements in neural circuits and ultimately, action. One of \\
the effects of this repair is disability. Cognitive function, with \\
negative academic effects on the acquisition of new information. \\
$\begin{array}{l}\text { Knowing this phenomenon, researchers conducted alternative } \\
\text { therapies to improve cognitive function. Researchers use writing } \\
\text { as a therapy for them. Writing has enormous therapeutic } \\
\text { benefits. Writing is also a healthy brain exercise to activate brain } \\
\text { cells and improve memory. This research used a qualitative } \\
\text { descriptive method which was conducted in the Adult Prison in } \\
\text { Blitar City. The research subjects used were 15 drug prisoners } \\
\text { treated in writing therapy. Data were collected from 15 prisoners } \\
\text { and given training in writing therapy. The research results are } \\
\text { presented using qualitative descriptive with the results that there } \\
\text { is an increase between before therapy and after therapy. They } \\
\text { can write and improve their cognition. }\end{array}$ \\
Keywords: drugs, writing, theraphy, cognitive
\end{tabular}


Salah satu dampak perbaikan ini adalah kecacatan. Fungsi kognitif, dengan efek akademis negatif pada perolehan informasi baru. Mengetahui fenomena tersebut maka peneliti melakukan terapi alternatif untuk meningkatkan fungsi kognitifnya. Peneliti menggunakan menulis sebagai terapi bagi mereka. Menulis memiliki manfaat terapeutik yang sangat besar. Menulis juga merupakan latihan otak yang sehat untuk mengaktifkan sel-sel otak dan meningkatkan daya ingat. Penelitian ini menggunakan metode deskriptif kualitatif yang dilakukan di Lapas Dewasa Kota Blitar. Subjek Penelitian yang digunakan adalah 15 Narapidana Narkoba dirawat dalam terapi menulis. Data diambiil dari 15 narapidana tersebut dan diberi pelatihan terapi menulis. Hasil penelitian disajikan dengan menggunakan deskriptif kualitatif dengan hasil bahwa terdapat peningkatan antara sebelum terapi dan sesudah terapi. Mereka bisa menulis serta meningkatkan kognisi mereka.

Kata kunci: obat-obatan, tulisan, terapi, kognitif

\section{PENDAHULUAN}

Permasalahan narkoba saat ini sudah mulai menjadi ancaman di dalam kehidupan masyarakat Indonesia. Tingkat penyalahgunaan narkoba telah merambah luas dan penggunanya meliputi berbagai usia. Pada tahun 2016, menurut laporan kinerja Badan Narkotika Nasional korban penyalahgunaan Narkoba di Indonesia tidak terbatas pada kalangan masyarakat yang mampu, tetapi sudah merambah ke kalangan masyarakat ekonomi rendah. Korbannya juga bukan hanya pada orang dewasa dan mahasiswa, namun pelajar Sekolah Menengah Umum (SMU) sampai pelajar tingkat Sekolah Dasar (SD) sudah ada yang menjadi korban. Data Badan Narkotika Nasional Republik Indonesia tahun 2008, menunjukkan bahwa 1,9\% dari jumlah penduduk Indonesia terlibat penyalahgunaan narkoba, dan pada tahun 2005- 2008 menunjukkan bahwa diperkirakakan 15 ribu orang tewas setiap tahun akibat penyalahgunaan narkoba. (Ismiati,2018)

Narkotika, Psikotropika, dan Zat Adiktif lainnya (NAPZA) adalah bahan atau zat yang bila masuk ke dalam tubuh akan mempengaruhi tubuh terutama susunan syaraf pusat/otak sehingga jika disalahgunakan akan menyebabkan gangguan fisik, psikis/jiwa, dan fungsi sosial. Susunan syaraf pusat atau fungsi otak merupakan bagian yang paling penting di dalam tubuh setiap manusia. Penyalahgunaan NAPZA menimbulkan dampak antara lain merusak hubungan kekeluargaan, menurunkan kemampuan belajar, ketidakmampuan untuk membedakan mana yang baik dan mana yang buruk. Mana yang halal dan yang haram, perubahan mental dan perilaku menjadi anti-sosial (psikopat), merosotnya produktivitas kerja, gangguan kesehatan, mempertinggi kecelakaan lalu lintas, kriminalitas, dan tindak kekerasan lainnya, serta berakhir pada kematian yang sia-sia (Hawari, 2004: III dalam Ulfah, 2015).

Penyalahgunaan narkoba juga berdampak pada kognitif manusia karena secara langsung narkoba dan obat-obatan terlarang lainnya menyerang system syaraf pusat. Gangguan terkait penggunaan tertentu obat-obatan dikaitkan dengan tingkat morbiditas penting di seluruh dunia. Berbagai macam obat yang diinduksi modifikasi neurobiologis telah 
dijelaskan; beberapa di antaranya dapat menjadi pembelajaran yang sempurna dan fungsi memori. Obat perangsang, seperti nikotin dan amfetamin, meningkatkan kognitif berfungsi pada dosis yang lebih rendah tetapi mengganggu kinerja memori pada dosis yang lebih tinggi. Obat depresan, seperti alkohol, dapat menyebabkan efek jangka panjang pada fungsi korteks prefrontal, mengganggu kemampuan kognitif.

Beberapa penelitian menunjukkan bahwa pengaruh obat psikoaktif pada pembelajaran dan memori dapat dijelaskan, setidaknya sebagian, karena mekanisme neurobiologis bersama terlibat dalam pembelajaran dan proses memori dan struktural dan fungsional yang diinduksi obat terdapat perubahan di otak. Secara anatomis, ada tumpang tindih penting antara saraf substrat pembelajaran dan memori dan kecanduan. Beberapa area yang menunjukkan tumpang tindih termasuk korteks serebral, hipokampus, amigdala dan striatum semuanya komponen dari sistem dopaminergik mesolimbik. (Portilla, 2018)

Sebgai contoh, yaitu amfetamin yang jika kelebihan akan menyebabkan kerusakan pada system dopamine atau neurotransmitter pada otak. Terjadinya peningkatan akifitas dopaminmenyebabkan terjadinya kerusakan sel. Hal ini terjadi karena defisit persisten dari fungsi neuron dopaminergic. Terganggunya system tersebut akan menyebabkan kerusakan otak jangka panjang karena terdapat banyak sekali daerah kaya dopamine di bagian-bagian penting otak terutama area yang mengatur gerakan, belajar, dan memori (Triswara, Carolia, 1917).

Pemerintah dalam hal ini, Badan Narkotika Nasional (BNN) dibantu masyarakat telah melakukan upaya pencegahan dan pengendalian perdagangan narkoba, sementara itu dalam norma sosial dan juga ajaran-ajaran agama telah menyebutkan bahwa menggunakan zat-zat yang memabukkan adalah perbuatan terlarang. Namun kenyataan menunjukkan bahwa korban penyalahgunaan narkoba terus ada, bahkan kasusnya terus meningkat. (Hawi, 2018)

Kerusakan kognitif tersebut mengakibatkan gangguan pada tindak eksekutif, kemampuan menganalisa dan kemampuan pembacaan terhadap suatu wacana. Jika dibiarkan secara terus menerus, maka pecandu nakoba akan mengalami penurunan dalam system saraf yang mengakibatkan penurunan kemampuan kognitif.

Melihat fenomena tersebut maka peneliti tertarik untuk merancang suatu strategi yang digunakan untuk meningkatkan kemampuan kognitif pecandu narkoba yang ada di Lapas Dewasa kota Blitar. Peneliti memakai pendekatan untuk menerapkan terapi menulis sebagai bentuk terapi terhadap pecandu narkoba. Menulis adalah proses kognitif yang sangat rumit. Kegiatan ini satu tingkat lebih yang dianggap paling sulit di atas kegiatan membaca pemahaman. Orang yang mampu membaca dengan baik belum tentu dapat menulis dengan baik, meski upaya telah dilakukan untuk meningkatkan kemampuan tersebut. (Sibarani, 2007)

Flower (1981) dalam Sibarani (2007) mengemukakan bahwa menulis merupakan kerja kognitif, antara lain: (1) lingkungan tugas, (2) penulis dan (3) tahapan penulisan. Lingkungan tugas terdiri atas dua proses pengkajian (examination) untuk (1) bagian: (a) tugas menulis dan (b) produk memperoleh sesuatu dibalik deskripsi objektif menulis. Penulis memiliki lima jenis atribut, atau sesuatu di balik fakta, yakni : (a) memori jangka panjang, (b) sekali bewujud penjelasan pengetahuan tentang topik, (c) pengetahuan penginterpretasian, (d) rencana penulisan antar bagian (text structure), dan (e) pengetahuan tentang keseluruhan. 
Melihat pentingnya menulis untuk meningkatkan kemapuan kognitif maka peneliti membuat suatu strategi berupa "Terapi Menulis untuk Meningkatkan Kemampuan Kognitf Pecandu Narkoba."

\section{METODE PENELITIAN}

Dalam penelitian ini penulis menggunakan pendekatan metode penelitian kualitatif, yaitu suatu penelitian yang berupaya menghimpun data, mengolah dan menganalisa data secara kualitatif dan menafsirkannyasecara kualitatif. Metodologi kualitatif sebagai prosedur penelitian yang menghasilkan data deskriptif berupa kata-kata tertulis atau lisan dari orangorang dan perilaku yang dapat diamati (Moleong, 2001: 9). Penulis menggunakan pendekatan kualitatif dalam melakukan penelitian agar dapat memiliki dan menyajikan data yang akurat dari pelaksanaan terapi menulis untuk pecandu narkoba di Lapas Dewasa Kota Blitar.

Teknik pemilihan informan dalam penelitian ini menggunakan teknik purposive sampling yang memberikan keleluasaan kepada peneliti dalam menyeleksi informan yang sesuai dengan tujuan penelitian, yang terpenting disini bukanlah jumlah info Dalam teknik pengumpulan data, penulis melakukan observasi, wawancara, dan dokumentasi. Penulis melakukan wawancara kepada 15 Orang Pecandu. Dan dari 15 orang tersebut mendapatkan terapi untuk strategi peningkatan kognitif mereka. Dari 15 orang tersebut data diolah dalam sebuah proses triangulasi. Setelah dilakukan wawancara, maka peneliti data melihat tingkat kerusakan kognnitif melalui tingkat kemampuan keterbacaan atau penulisan. Setelah itu, 15 orang tersebut mendapatkan terapi dan penulisan puisi dan essay. Hasil penulisan mereka dianalisa dengan menggunakan metode deskriptif kualitatif.

\section{HASIL DAN PEMBAHASAN}

\section{Penurunan Tingkat Kognitif Pada Pecandu Narkoba}

Dari hasil oenelitian yang dilakukan selama bulan Agustus 2019, peneliti menemukan adanya penurunan kemampuan kognitif terhadap pecandu narkoba di Lapas Dewasa Kota Blitar. Peneliti menggunakan skala Scors untuk menguji tingkat penurunan kognitifnya. Skala Scors merupakan suatu instrumen penelitian yang terdiri dari Scors 10 item pertanyaan yang meliputi ranah atensi, memori kerja, kecepatan pemrosesan, pertimbangan dan pemecahan masalah, pembelajaran dan memori verbal, pembelajaran dan memori visual, dan kognisi sosial Semakin kecil nilai Scors nya maka tingkat keparahan semakin tinggi.

Tabel 1. Jumlah Skala Scors pada Pecandu Narkoba Lapas Dewasa

\begin{tabular}{cc}
\hline Nama & Skor Scors \\
\hline $\mathrm{Ab}$ & 198 \\
$\mathrm{Da}$ & 183 \\
$\mathrm{Na}$ & 170 \\
$\mathrm{Ta}$ & 160 \\
$\mathrm{La}$ & 173 \\
$\mathrm{Sa}$ & 162 \\
$\mathrm{St}$ & 150 \\
$\mathrm{TT}$ & 175 \\
\hline
\end{tabular}

Miza Rahmatika Aini, Hesty Puspitasari - Terapi Menulis untuk 


\begin{tabular}{cc}
\hline $\mathrm{Hn}$ & 160 \\
$\mathrm{Sj}$ & 160 \\
$\mathrm{Sy}$ & 189 \\
$\mathrm{Nt}$ & 150 \\
$\mathrm{Sr}$ & 140 \\
$\mathrm{TY}$ & 155 \\
$\mathrm{NU}$ & 170 \\
\hline
\end{tabular}

Dari tabbel tersebut dapat dijelaskan bahwa semakin kecil nilai Scors maka semakin rendah tingkat kemampuan kognitif. Penilaian skala Scors meliputi kemampuan pembacaan terhadap suatu wacana, daya ingat jangka pendek, daya ingat jangka panjang, kemampuan dan ketrampilan sederhana seperti mengendarai sepeda motor, konsentrasi dan kemampuan dalam pengambilan keputusan. Bagi Pecandu narkoba yang sudah lebih dari empat tahun memakai narkoba maka kemampuan kognitifnya menurun. Semakin lama pemakaian narkoba maka semakin rendah tingkat kemampuan kognitifnya. Test terakhir adalah menceritakan kembali isi bacaan dan memparafrasekan isi paragraph. Hasilnya hampir semua pecandu narkoba yang berjumlah 14 orang tidak mampu menceritakan dan menuliskan kembali isi bacaan.

\section{Terapi Menulis untuk Meningkatkan kemampuan Kognitif Pecandu Narkoba}

Seperti yang diungkapkan Tarigan (2008:3) dalam Purnamasari (2014) bahwa menulis ialah menurunkan atau melukiskan lambang-lambang grafik yang menggambarkan suatu bahasa yang dipahami seseorang, sehingga orang dapat membaca lambang-lambang grafik tersebut. Dalam menulis diperlukan adanya suatu bentuk ekspresi gagasan yang berkesinambungan dan mempunyai urutan logis dengan menggunakan kosa kata dan tata bahasa tertentu atau kaidah bahasa yang digunakan sehingga dapat menggambarkanatau dapat menyajikan informasi yang diekspresikan secara jelas.

Menulis juga meningkatkan aktifitas otak dan kemampuan kognitif. Dalam penelitian Portilla (2017) disebutkan bahwa memori adalah bagian alami dari pembelajaran; keduanya diperlukan untuk perubahan perilaku itu mendahului kelangsungan hidup spesies.

Gangguan kognitif adalah konsekuensi yang mapan dari zat jangka panjang penyalahgunaan, dengan stimulan seperti nikotin, metamfetamin (MA) dan kokain yang menyebabkan deicits bidang fungsi eksekutif. Stimulan adalah golongan obat-obatan terlarang yang bisa negatif berdampak pada individu yang menggunakannya.

Mengetahui dan mengobservasi kondisi tersebut maka penulis melakukan terapi menulis sebagai suatu strategi untuk meningkatkan kognitif pecandu narkoba. Kemampuan kognitif terasah pada proses mendapatkan ide dan menganalisa. Dengan melakukan terapi menulis dalam waktu yang lama maka kecerdasan pecandu narkoba dapat terasah sedikit demi sedikit dengan catatan mereka tidak mengkonsumsi lagi narkoba selama terapi berlangsung.

Dalam terapi ini peneliti membagi peserta dalam dua kelompok. Kelompok pertama adalah menulis puisi bebas, dan kelompok kedua adalah menulis esai. Peneliti bersama kelompok mahasiswa memberikan materi kepenulisan dan pelatihan penulisan. Dalam satu bulan hasilnya terdapat peningkatan merek mampu menulis puisi dan esai. 
Hasil penulisan tersebut adalah sebagai berikut:

1 .

Penulisan puisi

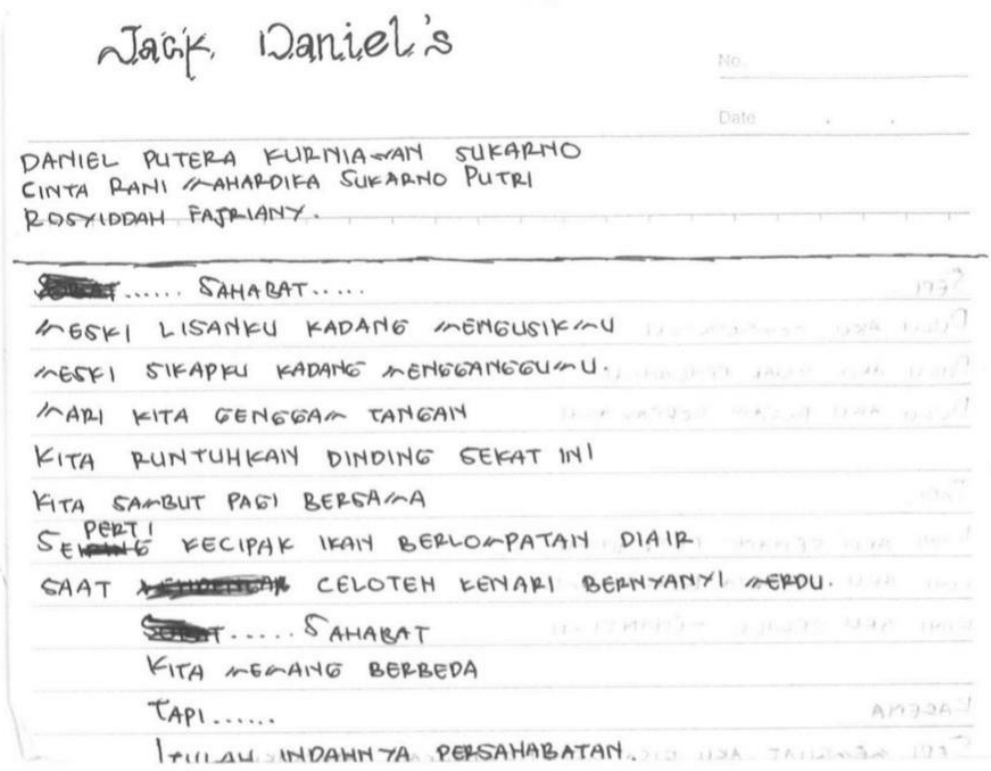

Gambar 1. Salah satu hasil Penulisan Puisi
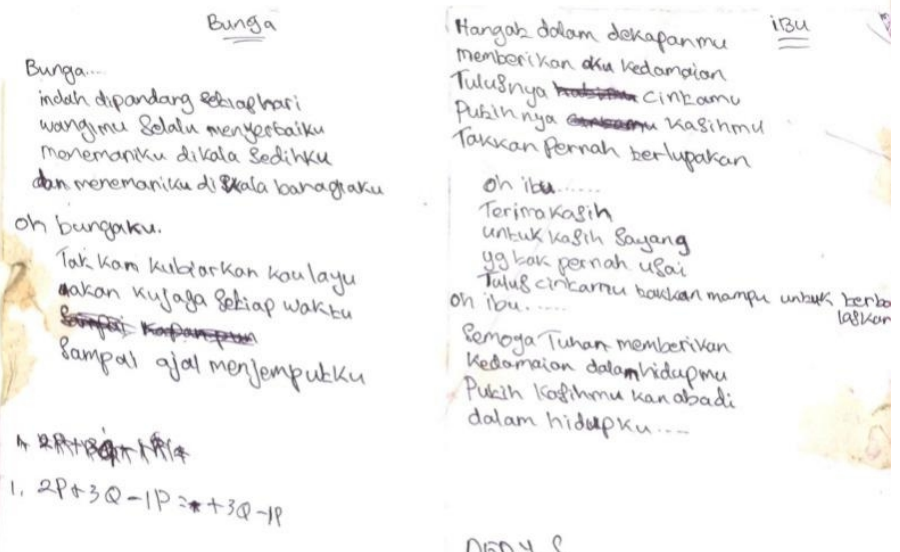

DEDY.S

Gambar 2. Salah satu hasil Penulisan Puisi 
Sudah cukup ber putor beberppa kali ber jacain mengitari Capangan hanya untuk melemaskan ofot yang kaker sypaya badan ken sehat semantrasa Schat eahir batin. Itulah awal anu melatu kan legiatinku dicapas blitar yang jauh dari tempat asalker. Teqap berdiri denqan Sejutr harapan... semua ini ake lake kan unture mempercepat waves disini suppaya expat berganti havi, havi havi sisnhuleuman aber disini, anu ing in semuarya cepat betakhir dengan sebuah perubahan hidup yang diharapvah.

aken memang dak pardoi menulis kate kata tetapi seti dak rya apa youg alue kasakan caat in bisa mengurang beban pivitanku dan bifa men curah kan apa yang alue kala tanpa harus sing sudah alue lewati burqant fore hingga malan tiba pada faot in alue menules apa yang alu trasa sudah meen brot persaanken Terima kasih ya tuhah buat havi in... saluhari yang sudah terlewat han sudah men jadikan

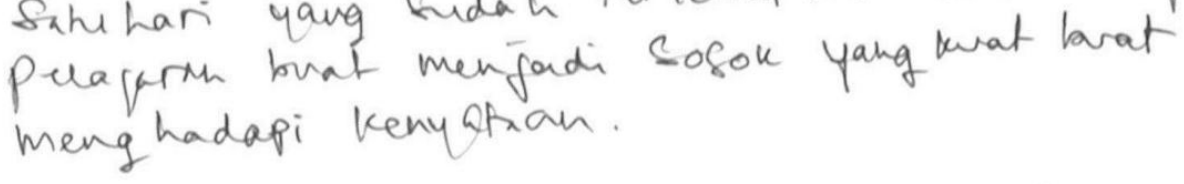

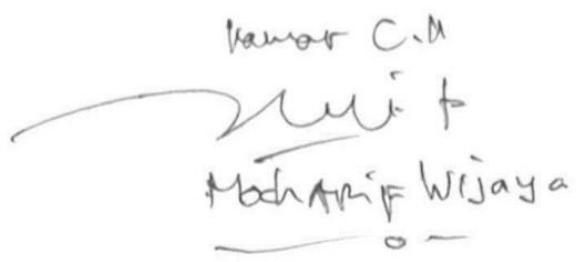

Gambar 3. Salah satu hasil penulisan Esai 
Dari hasil tulisan para pecandu narkoba, memang masih berupa tulisan bebas terutama esai. Namun kemampuan mereka sudah jauh berkembang dibandingkan sebelum mendapat pelatihan. Jika dikembangkan, terapi menulis dapat diterapkan untuk proses rehabilitasi. Untuk mengalihkan perhatian mereka terhadap kecanduan narkoba, pecandu dapat diarahkan untuk belajar di dunia kepenulisan. Semakin mereka menulis, maka kognitif mereka semakin meningkat. Kegiatan terapi menulis ini dapat diterapkan di lapas ataupun di Balai Rehabilitasi Narkoba.

\section{KESIMPULAN}

Dari penelitian yang dilakukan, bahwa pecandu narkoba mengalami kemunduran kognisi. Mereka tidak mampu melakukan ketrampilan sederhana. Dari penilaian skala scors banyak dari mereka berada dibawah rata-rata. Sehingga dapat disimpulkan bahwa narkoba sangat merusak akal dan pikiran manusia. Mereka tidak dapat lagi membaca dan menulis. Sehingga mereka kesulitan untuk melakukan tindak eksekutif.

Setelah dilakukan terapi, maka mereka mulai bisa melakukan pembacaan, analisa dan penulisan. Dari hasil karya mereka terdapat perkembangan daripada sebelum dilakukan terapi. Dari berkarya melalui penulisan, kemampuan kognitif mereka bertambah dan terjauhkan dari narkoba.

Namun dari sisi kemanusiaan mereka berhak untuk mendapatkan kesempatan untuk berubah. Di Lapas tempat mereka mendapatkan hubungan mereka bisa mengembangkan ketrampilan yaitu ketrampilan menulis. Selain meningkatkan kognitif mereka bisa berprestasi karena penulis bisa menjadi ladang pekerjaan dan bisa bermanfaat untuk mengembalikan dan memuliakan nama baik mereka dimata masyarakat.

\section{UCAPAN TERIMA KASIH}

Ucapan terimaksih tak terhingga diucapkan peneliti kepada berbagai pihak yang membantu terlaksananya penelitian ini. Kepada LPPM Universitas Brawijaya yang mendanai adanya pennelitian ini, Ibu Devita Sulistiana,S.Pd, Msi selaku Dekan FKIP Universitas Islam Balitar yang memberikan surat tugas. Bapak Andris selaku bagian di Lapas Kota Blitar, Segenap jajaran kasat narkoba kota Blitar yang membantu penelitian ini. Semoga penelitian ini bisa bermanfaat bagi pecandu narkoba khususnya dan masyarakat pada umumnya.

\section{RUJUKAN}

Hawi. 2018. Remaja Pecandu Narkoba :Studi tentang Rehabilitasi Integratif di Panti Rehabilitasi Narkoba Pondok Pesantren Ar-Rahman Palembang. Tadrib, Vol. IV, No.1, Ismiati. 2018. Strategi Badan Narkotika Nasional Kabupaten (BNNK) Aceh Selatan Dalam Upaya Pencegahan dan Penanganan Narkoba. Al Bayyan. Vol 24.No 2

Moleong. 2004. Metodologi Penelitian Kualitatif. Bandung: PT. Remaja Rosdakarya.

Portilla Juarez Claudia et al.2018. Influence of Drugs on Cognitive Functions. Intech-Open http://dx.doi.org/10.5772/intechopen.71842 
Purnamasari. 2014. Upaya Meningkatkan Aktivitas Dan Kemampuan Menulis Karangan Narasi Melalui Penggunaan Media Gambar Seri Pada Mata Pelajaran Bahasa Indonesia Kelas V Sekolah Dasar Negeri 04 Bingin Kuning. Skripsi: Universitas Bengkulu

Sibarani Berlin.2007. Penerapan Proses Kognitif Dan Terapi Cognitive Blocking Dalam Peningkatan Kualitas Pembelajaran Menulis. Diksi. Vol 4 No 2.

Triswara Regina,Carolia Novita.2017.Gangguan Fungsi Kognitif Akibat Penyalahgunaan Amfetamin. Majority. Volume 7 No 1

Ulfah, Nurbani.2015. Evaluasi Program Art Therapy Bagi Pasien Dual Diagnosis (NAPZASkizofrenia) di Rumah Sakit Ketergantungan Obat (RSKO) Jakarta.Empati: Jurnal Ilmu Kesejahteraan Sosial Vol 4 No 1. 